\title{
PELATIHAN PERHITUNGAN PAJAK PPH PASAL 21, PASAL 23, DAN PPH PASAL 4 AYAT 2 KEPADA KEPALA SEKOLAH, BENDAHARA, ADMINISTRASI SMP KOTA TANGERANG SELATAN GUGUS 02
}

\author{
Lativa, Rudi Sanjaya, Syarifah Ida Farida, Fikron Al Choir, dan Didi Sunardi \\ Program Studi Manajemen \\ Universitas Pamulang \\ Email : dosen01207@unpam.ac.id
}

\begin{abstract}
The purpose of the PKM activities is to maximize the performance of principal, treasurer, administration of SMP Kota Tangerang Selatan cluster 02. The focus is on school treasurer tasked with handling the use of BOS funds. BOS Treasurer has a tax obligation that is somewhat different than the government treasurer in general. Procedure of calculation of PPh article 21 on employee's salary is derived from calculating the entire gross income of a month which includes basic salary and allowances, then reduced by the existing deduction, then calculated net income a year. The PKM research object is the principal, treasurer, administration of SMP Kota Tangerang Selatan cluster 02. The problem is derived from the lack of knowledge and the school principal, treasurer related to the tax problems in the use of BOS funds (school operational Assistance). The training Program that will be provided by experts in the field of tax is expected to provide knowledge related to tax calculation of article 21, article 23, and PPh article 4 paragraph 2 to the principal, treasurer, SMP administration of Tangerang City South Cluster 02.
\end{abstract}

Keywords: Training, tax calculation of article 21, article 23, and PPh article 4 paragraph 2

\begin{abstract}
Abstrak
Tujuan pelaksanaan dari kegiatan PKM ini adalah memaksimalkan kinerja Kepala Sekolah, Bendahara, Administrasi SMP Kota Tangerang Selatan Gugus 02. Fokusnya yaitu pada bendahara sekolah yang bertugas menangani penggunaan dana BOS. Bendahara BOS mempunyai kewajiban perpajakan yang agak berbeda daripada Bendahara Pemerintah pada umumnya. Prosedur perhitungan PPh Pasal 21 atas gaji pegawai diperoleh dari menghitung seluruh penghasilan bruto sebulan yang meliputi gaji pokok dan tunjangan, kemudian di kurangi dengan potongan yang ada, kemudian dihitung penghasilan netto setahun. Objek penelitian PKM yaitu
\end{abstract}


Kepala Sekolah, Bendahara, Administrasi SMP Kota Tangerang Selatan Gugus 02. Masalah yang diambil berasal dari kurang pengetahuan dan pahamnya kepala sekolah, bendahara terkait permasalahan pajak dalam penggunaan dana BOS (Bantuan Operasional Sekolah). Program pelatihan yang akan diberikan oleh narasumber yang ahli di bidang Pajak diharapkan mampu memberikan pengetahuan terkait perhitungan pajak PPh Pasal 21, Pasal 23, dan PPh Pasal 4 Ayat 2 kepada Kepala Sekolah, Bendahara, Administrasi SMP Kota Tangerang Selatan Gugus 02.

Kata Kunci: Pelatihan, Perhitungan Pajak PPh Pasal 21, Pasal 23, dan PPh Pasal 4 Ayat 2

\section{A. PENDAHULUAN}

Kesadaran terhadap pentingnya suatu pendidikan dapat memberikan harapan dan kemungkinan yang lebih baik dimasa depan, telah mendorong berbagai cara dan perhatian di seluruh lapisan masyarakat dalam setiap gerak langkah dan perkembangan di dunia pendidikan. Terkait dengan terbatasnya anggaran pendidikan, kenaikan harga Bahan Bakar Minyak (BBM) yang diikuti dengan turunnya nilai tukar rupiah US dolar menimbulkan kenaikan harga kebutuhan pokok, seperti sandang, pangan, perumahan, dan kesehatan. Permasalahan tersebut secara langsung maupun tidak langsung berpengaruh negatif terhadap kemampuan masyarakat untuk mengakses layanan pendidikan.

Selama ini pemerintah selalu berusaha memecahkan masalah pemerataan pendidikan. Salah satu upaya untuk meningkatkan akses masyarakat terhadap pendidikan bermutu, yang mendapat alokasi anggaran cukup besar adalah program Bantuan Operasional Sekolah atau dikenal dengan BOS. Dalam penggunaan dana BOS tersebut, dana diprioritaskan untuk kebutuhan biaya operasional nonpersonalia, bukan biaya untuk investasi dan bukan biaya untuk kesejahteraan guru. Walaupun pada pelaksanaannya, ada beberapa jenis pembiayaan investasi dan personalia yang boleh dibiayai menggunakan dana BOS. Pengelolaan keuangan sekolah penting untuk dilakukan agar dana yang diperoleh dapat digunakan secara efektif dan efisien.

Pengelolaan keuangan sekolah yang baik dapat dilakukan dengan menggunakan: asas pemisahan tugas, perencanaan, pembukuan setiap transaksi, pelaporan dan pengawasan. Namun, hasil penelitian Suparjio (2000: hal v) menyatakan bahwa dalam pengelolaan keuangan di Sekolah Dasar, yang menjadi hambatan adalah masih minimnya rutinitas pembukuan setiap transaksi dan ketidaksesuaian antara perencanaan dengan pelaksanaan dan laporan keuangan sekolah. Berdasarkan hasil penelitian dilapangan tersebut, dapat diambil kesimpulan bahwa kemampuan sekolah dalam mengelola keuangan sekolah dapat dikatakan belum optimal.

Pentingnya pengelolaan dana BOS yaitu, dengan pengelolaan yang baik akan mampu membantu ketercapaian tujuan dari program BOS dengan efektif dan efisien. Pengelolaan dana BOS yang baik merupakan suatu keberhasilan sekolah dalam mengelola dana BOS, melalui suatu proses kerjasama yang sistematis mulai dari perencanaan, pelaksanaan, sampai dengan evaluasi. Untuk itu, kami Dosen Universitas Pamulang dan mahasiswa 
mengadakan Pengabdian Kepada Masyarakat (PKM) bekerjasama dengan SMP N 04 Tangerang Selatan. Salah satu aspek yang akan kita terapkan adalah pelatihan perpajakan terkait anggaran dana BOS.

Pajak adalah iuran rakyat kepada kas negara berdasarkan undang-undang sehingga dapat dipaksakan, dengan tiada mendapat balas jasa secara langsung. Pajak dipungut berdasarkan norma-norma hukum untuk menutup biaya produksi barang-barang dan jasa kolektif untuk mencapai kesejahteraan umum. Pajak merupakan salah satu sumber penerimaan Negara yang digunakan untuk melaksanakan pembangunan bagi seluruh rakyat Indonesia. Perbedaan keadaan ekonomi, budaya dan sejarah suatu negara berdampak kepada pola perpajakan Negara tersebut. Pajak Penghasilan Orang Pribadi umunya sulit dipungut dalam masyarakat yang banyak penduduknya, dikarenakan penyebaran-penyebaran penduduk yang tidak merata dan tingkatan penghasilan yang berbeda (Damanik dan Hamzah, 2010). Pajak merupakan sumber penerimaan negara yang paling utama dan yang paling besar pada APBN. Pajak merupakan sumber yang sangat penting dalam memenuhi dan menunjang kebutuhan negara. Oleh karena itu, dalam mensukseskan penerimaan pajak perlu adanya kesadaran dari berbagai pihak, terutama para wajib pajak untuk membayar pajak (ORTax, 2012).

\section{B. METODE PELAKSANAAN KEGIATAN}

Pada pengelolaan dana Bantuan Operasional Sekolah (BOS), terdapat aturan atau ketetapan yang berlaku yang sudah ditetapkan oleh pemerintah. Menurut UU no. 20 tahun 2003 tersebut, pendanaan pendidikan sudah diatur secara khusus dalam Bab XIII, yang substansinya antara lain : Pendanaan pendidikan menjadi tanggung jawab bersama antara pemerintah, pemerintah daerah dan masyarakat serta pengelolaan dana pendidikan berdasarkan prinsip keadilan, efisiensi, transparansi, dan akuntabilitas publik.

Transparansi pengelolaan dana BOS, transparansi menurut Krina (2003:14) bahwa transparansi adalah prinsip yang menjamin akses atau kebebasan bagi setiap orang untuk memperoleh informasi tentang penyelenggaraan pemerintahan, yakni informasi tentang kebijakan, proses pembuatan dan pelaksanaanya, serta hasil-hasil yang dicapai.

Dalam pengelolaan dana pendidikan, ada beberapa prinsip yang harus diperhatikan (PP no 48 Tahun 2008 pasal 59) antara lain prinsip keadilan, prinsip efisiensi, prinsip transparansi, dan prinsip akuntabilitas publik. Transparansi adalah keterbukaan atas semua tindakan dan kebijakan yang diambil oleh pemerintah (Muhammad, 2007). Keterkaitan dengan pengelolaan keuangan sekolah ini, partisipasi merupakan keterlibatan dan peran serta dalam menyampaikan ide dan gagasan, mengambil keputusan, melaksanakan, mengawasi, dan mengevaluasi dalam pengelolaan anggaran dana BOS. Partisipasi terliat dalam keterlibatan masyarakat, yaitu komite sekolah dan wali murid yang ikut serta dalam penyusunan rencana anggaran sekolah juga memiliki fungsi dapat memanfaatkannya untuk menyampaikan kritikan, masukan, dan lain-lain (Ristya, 2013).

Metode kegiatan ini berupa pemberian tips dan trik kepada para peserta. Berikut ini adalah tahapan pelatihan yang dilakukan:

1. Tahap persiapan, Tahap persiapan yang dilakukan meliputi:

a. Survey awal, 
b. Pemantapan dan penentuan lokasi dan sasaran. Setelah survey maka ditentukan lokasi pelaksanaan dan sasaran peserta kegiatan.

2. Tahap Pelaksanaan Pengabdian Kepada Masyarakat

Tahap ini akan diberikan penjelasan mengenai apa itu Audit Internal dana BOS. Sesi ini menitik beratkan pada pemberian penjelasan mengenai bagaimana penerapan audit internal.

3. Tahap Pelatihan

Untuk melaksanakan kegiatan tersebut digunakan beberapa metode pelatihan yaitu:
a. Metode ceramah
b. Metode tanya jawab
c. Metode simulasi

\section{HASIL DAN PEMBAHASAN}

\section{Tahap Persiapan}

Sebelum melaksanakan Pengabdian Kepada Masyarakat kami selaku Dosen Universitas Pamulang melakukan prasurvey kepada beberapa sekolah di wilayah Tangerang selatan. Berdasarkan data dan informasi yang kami dapatkan bahwa penerapan audit internal dan BOS masih belum terlaksana dengan baik. Hal ini menuntut para stakeholder sekolah untuk memahami mengenai pentingnya audit internal laporan keuangan pengunaan dana BOS. Oleh karena itu, kami Dosen Universitas Pamulang melakukan pertemuan dengan SMP N 04 Tangerang Selatan untuk memberikan solusi terhadap permasalahan mengenai perhitungan pajak PPh Pasal 21, Pasal 23, dan PPh Pasal 4 Ayat 2 kepada Kepala Sekolah, bendahara, administrasi SMP Kota Tangerang Selatan Gugus 02.

Setelah itu, TIM PKM yang terdiri dari lima orang Dosen UNPAM melakukan Forum Group Discussion (FGD) untuk mempersiapkan pelaksanaan Pengabdian Kepada Masyarakat (PKM) untuk tanggal di Kelurahan SMP N 04 Tangerang Selatan.

\section{Tahap Pelaksanaan Pengabdian Kepada Masyarakat}

Pelaksanaan Pengabdian Kepada Masyarakat di Lembaga Pemberdayaan Masyarakat pada tanggal 9 - 11 Desember 2019. Kegiatan dilaksanakan di Aula SMP N 04 Tangerang Selatan. Kegiatan ini terlaksana atas kerjasama Universitas Pamulang dengan SMP N 04 Tangerang Selatan. dengan tema "Pelatihan Perhitungan Pajak PPh Pasal 21, Pasal 23, dan PPh Pasal 4 Ayat 2". Kegiatan ini di ketua oleh Ibu Lativa dengan narasumber Bapak Rudi Sanjaya dan Bapak Didi Sunardi serta dibantu dosen UNPAM lainnya yaitu Drs. Fikron Al Choir, M.M., M.Pd. dan Syarifah Ida Farida, S.E., M.M. Kegiatan PKM ini dihadiri kebanyakan dari kalangan Kepala Sekolah, Bendahara, Administrasi SMP Kota Tangerang Selatan Gugus 02.

\section{Tahap Pelatihan}

Untuk melaksanakan kegiatan tersebut digunakan beberapa metode pelatihan yaitu:

1. Metode ceramah

Metode yang digunakan dalam pelatihan SDM dimulai dengan memberikan ceramah atau presentasi dengan tema "Pelatihan Perhitungan Pajak PPh Pasal 21, Pasal 23, dan PPh Pasal 4 Ayat 2 Kepada Kepala Sekolah, Bendahara, Administrasi SMP Kota Tangerang Selatan Gugus 2", dengan narasumber Bapak Rudi Sanjaya yang dibantu oleh Bapak Didi Sunardi sebagai moderator. 
2. Metode tanya jawab

Setelah sesi ceramah sudah selesai, maka dilanjutkan dengan sesi tanya jawab. Hasilnya, peserta sangat antusias untuk menanyakan bagaimana cara Audit internal dana BOS bisa berjalan dengan baik. Peserta yang bertanya kami berikan cendremata dari Universitas Pamulang dan sumbangsih dari dosen-dosen UNPAM.

3. Metode simulasi

Pelatihan ini juga diberikan metode simulasi, sehingga peserta langsung dapat mempraktekan apa yang sudah disampaikan. Apabila ada kendala maka langsung dibantu pada saat pelaksanaan PKM. Simulasi penting dilakukan untuk mengetahui seberapa besar tingkat pengetahuan dan ilmu yang diserap pada saat pelatihan.

\section{KESIMPULAN DAN SARAN}

\section{Simpulan}

Pelaksanaan kegiatan Pengabdian Kepada Masyarakat oleh Lembaga Penelitian dan Pengabdian Masyarakat (LPPM) Universitas Pamulang yang dilakukan oleh dosen-dosen program studi Manajemen telah berjalan dengan lancar dan mendapat sambutan hangat dari tempat pelaksanaan kegiatan ini yaitu Kepala SMP N 04 Tangerang Selatan. Harapan kami dengan pengabdian ini dapat menambah ilmu yang bermanfaat dalam hal perpajakan terkait dana BOS. Dalam laporan kegiatan ini mungkin banyak kekurangan yang ada, untuk itu kami berharap masukan dan kritikan dalam rangka perbaikan untuk kegiatan-kegiatan pengabdian masyarakat di masa yang akan datang. Semoga kegiatan pengabdian masyarakat ini dapat bermanfaat bagi masyarakat sekitar lingkungan Universitas Pamulang dan lainnya.

Akhirnya, kami mengucapkan terima kasih kepada seluruh pihak yang telah mendukung kegiatan yang kami laksanakan dan kami mohon maaf apabila dalam laporan ini banyak ditemukan kekurangan.

\section{Saran}

Berdasarkan hasil kegiatan Pengabdian Kepada Masyarakat, maka kami dari Tim Dosen Universitas Pamulang memberikan saran diantaranya sebagai berikut:

1. Untuk pihak sekolah dan seluruh jajaran stakeholder untuk lebih mengedepankan pengelolaan keuangan yang lebih optimal dan menyelesaikan pembayaran pajak terkait dana BOS yang telah dijelaskan dalam materi pelatihan.

2. Adanya kontribusi dari pihak universitas untuk bisa memberikan fasilitas dalam pelayanan kepada masyarakat dalam bentuk sarana dan prasarana.

\section{DAFTAR PUSTAKA}

Bastian, I. (2013). Sistem Akuntansi Sektor Publik, edisi 3. Jakarta: Salemba Empat.

Damanik, L., \& Hamzah, . (2010). Perhitungan Pajak Penghasilan Pasal 21 Pada PT.Ika Utama Trasfer Express. Skripsi. Universitas Sumatra Utara. Medan.

Direktur Jendral Pajak. (2009). Peraturan Direktur Jendral Pajak Nomor PER - 31/PJ/2009 Tentang Pedoman Teknis Tata Cara Pemotongan, Penyetoran dan Pelaporan Pajak Penghasilan Pasal 21 dan/atau Pajak Penghasilan Pasal 26 Sehubungan Dengan Pekerjaan, 
Jasa, dan Kegiatan Orang Pribadi. Diakses dari http://www.ortax.org/ortax/? mod=aturan\&page=show\&id=13796 Pada 28 Oktober 2019 Pukul 12.14 WIB.

Hamid, M. (2007). Pendidikan Kesetaraan Paket A, Paket B, dan Paket C. Jakarta: Depdiknas.

Krina, L. L. P. (2003). Indikator dan Alat ukur Prinsip Akuntabilitas, Transparansi dan Partisipasi. Jakarta: Badan Perencanaan Pembangunan Nasional.

Mardiasmo. (2009). Akuntansi Sektor Publik. Yogyakarta: Andi.

Mulyono. (2010). Manajemen Berbasis Sekolah. Yogyakarta: Ar-Ruzz Media.

Peraturan Mendiknas nomor 69 Tahun 2009 tentang standar biaya operasi nonpersonalia.

Peraturan Pemerintah 48 tahun 2008 tentang pendanaan pendidikan, biaya non personalia.

Ristya, D. A. (2013). Transparansi, Partisipasi, dan Akuntabilitas Pengelolaan Anggaran Dana BOS Dalam Program RKAS di SDN Pacarkeling VIII Surabaya. Jurnal Kebijakan dan Manajemen Publik, Vol. 1 No. 2.

Suparjio. (2000). Pengelolaan Keuangan Di Sekolah Dasar Se-Ranting Dinas P dan K Kecamatan Piyungan Kabupaten Bantul Yogyakarta”. Abstrak. Skripsi. FIP-UNY.

Undang-Undang no. 20 tahun 2003 tentang pendanaan pendidikan. 